\title{
INTERNATIONAL GRADUATES: PAKISTANI FULBRIGHT ALUMNI ON THEIR RETURN TO PAKISTAN
}

\author{
Maria Staton ${ }^{1 *}$, Rabeya Jalil ${ }^{2}$ \\ ${ }^{1}$ Assistant Professor, Ball State University, USA, polyakov@bsu.edu \\ ${ }^{2}$ Assistant Professor, Beaconhouse National University, PAKISTAN, rabeyajalil2013@gmail.com \\ ${ }^{*}$ Corresponding author
}

\begin{abstract}
The study contributes to the under-explored topic of international alumni and their professional activities back in the home countries, and especially the impact such activities may have on the alumni's communities. The study is based on interviews with six Pakistani Fulbright alumni, three males and three females, who had graduated from art and design institutes in the U.S. in the last seven years; the alumni discuss the influence of their U.S.A. experience on their teaching and involvement in the community. The interviews sought the answers to the following two questions: 1 . What was the impact of the Fulbright program on the alumni's teaching? and 2. What were the alumni's perceptions, informed by their Fulbright period, of the crossnational humanistic influence of art on human relations? The questions were informed by the recently acknowledged fact that art practice is an effective means of reaching out across groups of society. Educators' experience confirms that art helps students to interact with peers of different social backgrounds; practicing art allows students to communicate more deeply and has a harmonizing effect for all the participants. It was hypothesized that Fulbright experience may trigger off changes in the alumni's pedagogy towards a more student-oriented approach; it was also hypothesized that Fulbright alumni may see more clearly the link between student-oriented teaching and humanistic relations in society, especially between the less privileged and more privileged groups of population. The results of the study included the following. All six interviewees pointed out that the Fulbright program had a positive impact on their teaching and academic experiences. Specifically, it enabled them to move from lecturing to more interactive student-centered teaching styles. Examples included taking students out of the classroom into real-life settings, giving more value to a "relational, interactive and collaborative space" rather than just a "speculative one," and practicing inclusive pedagogy (teaching autistic and deaf students). Likewise, all six interviewees indicated that there is a link between their innovative pedagogy and broader humanistic projects which they have launched since their return to Pakistan. The study concluded that when interacting with domestic students, the Fulbright graduates were transferring the skills they received abroad, thus becoming informal ambassadors of new ideas and practices. In this respect, Fulbright graduates have potential to influence Pakistan's academic and cultural development; therefore, it is important to establish closer contacts with them, as well as maintain these links for extended time.
\end{abstract}

Keywords: international alumni, Fulbright Program, art and design education, Pakistan, United States 


\section{INTRODUCTION}

During the last two decades, internationalization has become one of the noticeable trends in higher education. Internationalization is "the process of integrating an international dimension into the teaching, research, and public service function of the institution" (Hudzik \& Stoh, 2012, p. 67). It touches on questions of the institution's quality and prestige, as well as its competitiveness and innovation potential (Rumbley, 2012, p. 3). Colleges and universities are admitting consistently larger numbers of students from abroad, modifying along the way their curricula and pedagogy towards teaching an increasingly diverse student population. For the United States, the Institute of International Education (IIE, 2016) reported that the number of international students surpassed one million for the first time during the 2015-16 academic year an increase of seven percent from the previous year - and reached 1,044,000.

The study of the internationalization of higher education has gained momentum over the last two decades and has become "a visible component of general publication on higher education" (de Wit \& Urias, 2012, p. 102). The focus tends to be on certain areas, such as internationalization of the curriculum, mobility of students and academic staff, and cross-border higher education collaboration, including knowledge transfer and development (Hudzik, 2015, p. 95-96). However, some other areas of research, such as international alumni, are left largely unexplored. This is indeed surprising because those alumni who return home have the capacity to contribute to their countries' progress on all four levels of national development: academic, economic, political, and socio-cultural (Internationalizing, 2015). On the academic level, international alumni can improve the quality of domestic higher education through developing faculty expertise and garnering best practices from peers abroad. On the economic level, they can help to build a skilled labor force that, in the long term, may spur national economic development. On the political level, international alumni may become part of public diplomacy efforts that aim to establish people-to-people and institution-to-institution relationships, as well as the creation of a positive national image. Such efforts in turn assert "soft power," or "the power of ideas and culture to influence the friendship, disposition, and actions of others" (Internationalizing, 2015). On the socio-cultural level, international graduates' direct experience of other countries and ongoing collaboration with colleagues abroad can increase tolerance for difference and appreciation of diversity, and in this way influence the climate of teaching and research in the alumni's countries (Internationalizing, 2015).

\section{2 . LITERATURE REVIEW}

Some highlights in the existing literature on international alumni include the following: international graduates' loyalty to their educational institutions and the ensuing fundraising opportunities; mobility of international graduates; alumni outreach ${ }^{1}$ and the impact of international alumni on their home institutions and countries; and Fulbright alumni.

\subsection{International Alumni's Loyalty to Their Educational Institutions}

Practical measures to reach out to international alumni have increased in the last twenty years, largely due to the spread of the Internet which made it easier to maintain relations over distance (Basinger, 1999; Clift, 2010). Practitioners noted when working with international alumni that the latter were frequently more loyal to their host institutions than native-born graduates. This loyalty was attributed largely to the emotional ties that are stronger in foreign students because studying abroad is a game-changing experience for them (Pulley, 2009 , p. 21; Read, 2009, p. 11). Foreign students typically make considerable sacrifices to study in a host country, such as leaving behind friends and family and often having to master a new language, so they tend to focus on what they want to get out of their experience. If this experience is good, they are often "keenly aware of it and grateful for the advantages conferred by a degree earned abroad" (Pulley, 2009, p.21).

In connection with the strong loyalty of international graduates to their host educational institutions often comes the question of fundraising. If institutions go global in outlook and practice, for example, by giving greater attention to global learning in the curriculum (Read, 2009, p. 12), it creates positive collegiate experience, which in turn makes it more likely that alumni would be generous in giving to their host educational institutions (Connor, 1999; Barth, 1998). Hudzik (2015) claimed, "[t]here have been numerous examples of international alumni contributing millions and tens of millions to their alma maters" (p. 130). The role of alumni as fundraisers is especially important in countries with a long tradition of philanthropy, such as the Unites States. In countries without such tradition, rising awareness about giving to ones' alma mater can

\footnotetext{
${ }^{1}$ Alumni outreach is a program providing services to graduates who have moved away from their school of graduation and might not otherwise have access to those services.
} 
be done through alumni activities and campaigns, which in turn are dependent on long-term friend raising and alumni outreach (Sporn, 2007, p. 142).

\subsection{Mobility of International Alumni}

The connection between the institution and alumni should be of mutual benefit (Walker, 2011, p. 41) and go beyond the mere opportunities for fundraising. A bulk of literature is devoted to the benefits that both the home and host countries have to offer in order to retain highly skilled international graduates. An international student's decision to return to their home country or to stay in the country in which they studied may have drastic consequences not only for the level of education and academic research in the host and home countries, but ultimately for the countries' economies as well. Some researchers maintain that the flow of immigrants back home is a "brain drain" for the U.S. because the country is losing out in terms of retaining talented foreign students, which ultimately results in fewer companies and jobs and stunted long-term economic growth. To stop this "brain drain," they call for an immigration policy overhaul which would allow highly skilled professionals to stay in the country where they got their advances degrees (Han, Stocking, Gebbie, \& Appelbaum, 2015; Wadhwa, 2009). Other researchers, on the contrary, have argued that boosting the "stay rate" of international graduates puts their home countries at a disadvantage. Emerging and developing economies make significant financial and intellectual contributions to the academic systems of the developed countries where they send their students, and if the students decide not to return after graduation, it cripples the home countries' developmental prospects (Altback, 2013; Teffera, 2005). In Africa, for example, the numbers of highly skilled specialists leaving their home countries have reached disturbing proportions (Amazan, 2014, p. 170).

Yet another group of researchers prefer to speak not of the "brain drain" but of the "brain exchange" or "brain circulation" (Saxenian, 2005). They say that the same students who left their home countries for education abroad are now returning home to establish business relationships or to start new companies while maintaining their social and professional ties to their host countries (Saxenian, 2005, p.2). The motivation to return to a home country is becoming as strong as the motivation to stay in a developed country, especially in view of the blossoming economies in such countries as China and India (Han, Stocking, Gebbie, \& Appelbaum, 2015; Banks \& Bhandari, 2012, p. 393). To make the prospect of returning home even more attractive, source countries develop additional measures to retain the brightest students as well as convince those who have gone abroad to return home. Brazil, for example, funds students to study abroad with the requirement that they return after completing their studies. Other countries offer tax breaks, grants, and other incentives to convince ex-patriots to return (Altbach, 2013).

\subsection{The Impact of International Alumni on Their Home Institutions And Countries}

When it comes to the impact of international alumni on their home institutions, most researchers agree that it is an important, but underdeveloped area of study. Research that tracks graduates of any kind, let alone international ones, through the medium- to long-term development of their careers is rare. One reason for this is the cost of such research - to track alumni, particularly international alumni, over extended periods is expensive and, therefore, practically challenging (Cuthbert, Smith, \& Boey, 2008). Another reason is the lack of theoretical and methodological approaches to obtaining hard data; more specifically, it is the difficulty of making demonstrable connections between the international graduates' education and the impact they have on academic institutions and sometimes on society. However, some research on the international alumni's long-tem impact does exist. A recent study was conducted by the Department for Business Innovation and Skills in the United Kingdom; among its other objectives, it had a goal to develop understanding of the impact of international graduates on their countries of origin. The study identified that, as higher-performing employees, international graduates introduced a number of measurable benefits to their employers and economies. The study projected that international alumni could bring about positive changes in education, capacity building, societal development, and possibly politics, which would increase in time as the alumni became more influential (Mellors-Bourne, Humfrey, Kemp \& Woodfield, 2013).

Another study of the impact international alumni can have on their home countries was undertaken by two Australian researchers based on the data provided by Australian government-sponsored Indonesian Fellowships from 1970-1989 (Cuthbert, Smith, \& Boey, 2008). The respondents reported that many advantages accrued from their international (Australian) study, such as promotions and pay rises, as well as increased opportunities to earn additional income. Almost all respondents stated that their international experience "had changed their views and practices" (Cuthbert, Smith \& Boey, 2008, p.12). However, many respondents also claimed that their careers depended more on bureaucratic departmental policies rather than on their individual expertise. A small group of respondents said that when they returned to their former place of employment after graduation, nothing had changed for them. "For a number of graduates, this sense of the irrelevance or futility of their Australian study was exacerbated by the lack of ongoing contact with the 
university at which they had studied" (Cuthbert, Smith, \& Boey, 2008, p.12).

Currently, the Institute of International Education (IIE) sponsored by the U.S. Department of State is conducting a tracking study of the graduates of the Ford Foundation International Fellowship Programs (IFP) focused on social justice and sustainable change. In April 2016, IIE published the first report of the study yielding the findings from their 10-year research. The findings show that "funding the post-graduate academic pursuits of emerging social justice leaders from marginalized groups leads to significant, measurable benefits for communities and organizations in their countries and throughout the world" (IIE-IFP, 2017). According to the report, the measurable benefits amount to the following: over 900 out of 4,300 IFP alumni created new programs and organizations which have impacted 9.5 million adults and children in the IFP countries; $84 \%$ of IFP alumni report making improvements in the organizations where they work or volunteer as a result of their IFP fellowship, and IFP alumni have created nearly 34,000 products and forms of outreach related to social justice. The report also indicates that over $95 \%$ of IFP alumni remain in touch with each other (IIE-IFP, 2017), which may be a significant factor in achieving the impressible results listed above.

\subsection{Fulbright Alumni}

Of the numerous programs in higher education with a large number of international graduates, the Fulbright program is the largest, with the FY16 budget of over $\$ 236$ million. The importance of Fulbright, and other international programs in higher education sponsored by the Department of State, has increased considerably after 9/11, mainly because they make an excellent public diplomacy tool (Abbas, 2015, p.5). The Fulbright Program, especially the part of it that targets foreign students and scholars, has significant potential to alleviate international tensions by putting a human face on politics, specifically, by promoting internationalization of professions and increasing the rates of cross-cultural research (Demir, Aksu, \& Paykoç, 2000, p. 104). Additionally, foreign Fulbright alumni are reported to have a teaching perspective and professional work style which are different from what is typically adopted in their native land (Demir, Aksu \& Paykoç, 2000, p. 104). Another frequently cited effect of the Fulbright Program concerns the role of Fulbright alumni in developing new curricula and starting new plans in their home countries, sometimes in collaboration with a foreign institution (Demir, Aksu, \& Paykoç, 2000, p. 104).

A Fulbright scholarship also results in social and personal change. Fulbright alumni cite the benefits of having experience in an international context, broadening their world perspectives, developing international networks, and transferring knowledge across cultures (Biraimah \& Jotia, 2013, p. 451). A powerful factor in maintaining these benefits for Fulbrighters is staying in touch, both among themselves and with their host institutions. To help Fulbrighters retain their international links, the Department of State opened an alumni office in 2003 , one of the goals being to gain a better understanding of the international exchanges' longterm benefits (Wilhelm, 2013). To promote interconnectedness between Fulbright alumni, the State Department has started holding Fulbright alumni conferences in specific areas of research. In 2010, it established an "innovation fund" which provides small grants to alumni of the Fulbright and other U.S. government exchange programs to start or continue projects overseas; in 2015, the State Department awarded \$I million to such efforts (Wilhelm, 2013). Yet another endeavor on the part of the Department of State is to fund tracer research projects aimed at discovering the Fulbright education's impact on alumni who returned to their countries of origin. One such project, funded by the Fulbright Commission for Israel, was conducted among Israeli academics that had been Fulbright graduate students in the U.S.A. The project found out, among other things, that while American scientific standards became a model for the Israeli scientists and were imported into their work environment, Israeli culture and identity were not relinquished but, on the contrary, became even more evident (Tubin \& Lapinot, 2008, p. 215). By studying the scientists' experience from a perspective of $3,5,10$, and more than 20 years, the project also concluded that their Fulbright period had considerable impact on the scientists' academic career (Tubin \& Lapinot, 2008, p. 215).

The Fulbright Program in Pakistan is the largest Fulbright program in the world (Fair, 2011), which can be partially explained by to the uneasy history of Pakistan-U.S. relationship. The start of the U.S.A. drone attacks of Pakistan in 2004 caused strong anti-America feelings among the Pakistanis (Abbas, 2015, p.9). As a response, the U.S. Department of State has considerably increased the scope of its public diplomacy initiatives in Pakistan, which included the Pakistani Fulbright program, in the effort to alleviate the antiAmerican sentiment in the country. Several agencies and individual researchers have already studied the Fulbright Program's effects in this respect. In 2014, the U.S. Agency for International Development (USAID) commissioned an evaluative study of the Fulbright Student Program in Pakistan with the objective to analyze the Program's development and educational impact (Abbas, 2015, p.9). In 2015, Abbas (2015) examined how the Pakistani Fulbright program had influenced its participants in their perceptions about the American people, on the one hand, and U.S.A. foreign policy, on the other. 


\section{INTERVIEWS WITH SIX PAKISTANI FULBRIGT ALUMNI}

The part that follows is an attempt to continue the dialogue with Pakistani Fulbright alumni about their American experience; specifically, we are interested in the effects of the Fulbright education on the alumni's professional life on their return to Pakistan. One of the authors of this article, Rabeya Jalil, spent three years (2010-2013) as a Fulbright scholar at the Teachers College of Columbia University. In addition to completing graduate courses towards a specialization in studio and visual arts, curriculum design, special education, and artistic development in fresco painting, Jalil conducted voluntary workshops on campus in her areas of expertise (printmaking, ceramics and sculpture) and led a student art club that facilitated artists' talks, collaborative projects, and hands-on workshops for educators. In performing these tasks, she took the role of a "student ambassador of Pakistan" and tried to use every opportunity to change the negative stereotypes of Pakistan and Pakistanis among the American people. On her return, she took the same role of a "people's ambassador" in regard of the Unites States and shared her positive American experience with students, coworkers, and friends.

Back in Pakistan, Jalil has been interacting with other Pakistani Fulbright alumni. In doing so, she became interested in conducting an informal study aimed at generating an account of her interlocutors' experiences as U.S. Fulbrighters. Jalil interviewed six Pakistani Fulbright scholars (three males and three females) who had graduated from art and design institutes in the United States in the last seven years. Her goal was to get the answers to the following two questions: 1. What was the impact of the Fulbright program on the alumni's teaching? and 2. What were the alumni's perceptions, informed by their Fulbright period, of the crossnational humanistic influence of art on human relations? Both questions were informed by the recently acknowledged fact that art practice is an effective means of reaching out across cultures; as a result, art is beginning to be included in educational curricula, regardless of the area of studies (Higson \& Liu, 2013, p. 113-14). Educators' experience confirms that art helps students to interact with different nationalities and form connections with other cultures (Higson \& Liu, 2013, p. 113-14). In a broader context, practicing art allows students to communicate more deeply and has a harmonizing effect for all the participants. A combination of the Fulbright alumni's potential to have an impact on their home institutions and the crossnational humanistic influences of art, especially if the latter is systematically used as part of the curriculum, may prove to be a powerful tool in shaping international public relations.

\subsection{The Fulbright Alumni's Responses on The Impact of The Program on Their Teaching Practices and Academic Experiences}

Several interviewees observed that their Fulbright stay in the U.S.A. had enabled them to make significant changes in their pedagogy. More specifically, they moved from a lecture-based class to more interactive student-centered teaching style.

"My focus in my teaching methodologies is to not have a lecture-based environment in the class; rather I initiate discussion, asking students questions, allowing them the freedom to disagree. Instead of sticking to one textbook, I introduce to the students essays written by critics dated $20^{\text {th }}$ century to present. This allows the students to exercise their comprehensive abilities, and be able to relate to the text in their own personal practices." (Natasha Jozi)

The interviewee quoted above was also aware of the pedagogical significance of taking their students out of the classroom into real-life settings in order to demonstrate to them how academic knowledge is connected to life experiences.

"I also decided to work on an initiative to promote experimental art in Pakistan. I was awarded the Alumni Small Grant under which I worked with art students, national and international artists and engaged the local craftsman. The initiative was to bring forward an exhibition introducing new media and interactive art experience. The initiative culminated in the form of an art exhibition titled 'We Are All Mad Here' at Pakistan National Council of the Arts (PNCA), and the exhibited works ranged from video works, to live performances to interactive installations. The exhibition was well attended and received by the press, where the audience showed intrigue, curiosity at the same time, questioning the agency of art and what is art. Audiences were initially inhibited in participating in any performance as an audience we keep a distance with the art work and gallery culture doesn't allow one to cross a certain barrier, hence during the exhibition the visitors realized that they need to repeat any such act, rather they could interact, participate and be art of the work." (Natasha Jozi)

Another interviewee stated that after her return to Pakistan she changed her work ethics by giving more value to a "relational, interactive and collaborative space" rather than just a "speculative one" (Hurmat ul Ain). 
Yet another interviewee became interested in inclusive pedagogy, especially as it applied to teaching autistic and deaf students. He said,

"I designed tools and solutions for myself as well as for other gifted self-advocates on the Autism Spectrum, extreme learners, under the paradigm of Universal Design for Learning (UDL)." (Qazi Fazli Azeem)

Not so long ago, the same interviewee interacted with the United States Educational Foundation in Pakistan. In the capacity of Fulbright alumnus, he supervised an art competition based on the theme "Pakistan-USA Educational Cooperation" at the Deaf Reach School in Karachi during the U.S. State Department's International Education Week (IEW) - 2015.

Yet, another interviewee said that he was a practicing filmmaker for almost a decade before he went to film school on his Fulbright scholarship, yet it was his schooling that taught him, first, to be appreciative of other people's filmmaking practices, and, second, to (interactively) teach the skills in which he himself is trying to grow.

"My course of study had a profound impact on my practice as well as my approach to how I thought about film. For one thing, the school helped me create a mental map of all the skills and areas of exploration that filmmaking entailed. This was very useful. Instead of learning and finding out about skills randomly, I could approach the process methodically and create a prioritized list of things I wanted to know more about, familiarize myself with, delve into deeply and/or just brush up upon. This has been hugely helpful in helping me practice ever since. Filmmaking is a hugely diverse and collaborative (mostly) art form -and knowing where to look for a collaborator and/or skill can sometimes really make all the difference. l's also helped me and continues to help me forge artistic partnerships and also continues to educate me about other people's practice - which is essential to growing. And lastly -despite my ten years of working in the field I never thought myself qualified enough to teach. Art school is what gave birth to my career as an educationist. I was not only able to look at the discipline as an art form that I am trying to grow in but also as an art form and a skill that I could teach that I could create curricula in." (Bilal Sami)

\subsection{The Fulbright Alumni's Responses on The Humanistic And Cross-National Role of Art in The World}

Reflecting on the beginnings of his interest in art's potential to address national and international problems; one interviewee said that he first got interested by joining the "Hacking Art" group, the first media lab at the Massachusetts Institute of Technology (MIT).

"We were strangers, united by our common passion for Arts and Design as tools to make a difference in society, tackling on some of the biggest challenges in the world. I joined a group of students, who wanted to re-purpose Olafur Eliasson's Little Sun solar lamp, making a solar-powered water purifying device from it. ... This connected with the way I wanted to practice design for the rest of my life, my aspiration was to make art for a societal impact, inspiring deeper conversations about larger international issues, such as inclusion in education and society. Returning to Pakistan around a year and a half ago, I have been translating what I saw and learned, curating and choosing my experiences, sharing where they are relevant and thinking deeply about the differences between the two societies, as well as the similarities. My post-Fulbright experiences have involved negotiatin my older identity and my current, multi-cultural one, using Design (with a capital $D$ ) to try and solve real-world problems through collaborative design interventions." (Qazi Fazli Azeem)

Another realization of this individual was that bridging the gap between different layers of society is possible through bringing together art for the masses, or the so-called low art, and art for the cultivated, or high art.

"Often we see a divide between the high and low art, and often read about the art/craft debate. I decided to invite the craftsmen and represent themselves in an art gallery along with other artists questioning the hierarchy of art. Also the craftsman (truck artist) was invited to paint a mural live at the opening, highlighting the process of the work also making the craft a performative act rather than just exoticizing the object and its beauty." (Natasha Jozi)

Other interviewees said that one factor contributing to poverty and other current problems in Pakistan was a lack of interactive discourse and a dearth of channels for debate. In this connection, they viewed art as "a domain for political and lobbyist exchange" and "a channel of reenactment and portraiture of self and others" (Hurmat ul Ain). To provide one such channel, one artist designed a project series called Guest Room. This series is

"a symbol of hospitality, generosity, cultural expectation of collectivist thought and a space for restitution of standardized lifestyle. Here the lines of private-public, familiar and the strange, self and other were 
IJAEDU- International E-Journal of Advances in Education, Vol. III, Issue 9, December 2017

constantly being blurred and revisited. The work 'Guestroom' is an attempt to capture traces of memory through reenactment and self-portraiture. And like many of my other works, the reenactment serves as a tool for remembrance, resolve and fictionalized narrative." (Hurmat ul Ain)

One other interviewee's response to the question about the role of art and design in building human relations around the world was as follows:

"Art and more specifically self-expression isn't just cross-national and humanistic; it's almost animalistic. The ability to express emotion and thought through a process that transcends even language is what makes us intelligent beings. The animal kingdom has different ways of expressing themselves that approach something that can be considered language. But the ability to take that to a level of abstraction gives us human nuance and alternative method of expression. This unites us, as does the ability to watch, listen and form an opinion about what we are ingesting purely on our assessment of it as someone else's expression." (Bilal Sami)

\subsection{The Fulbright Alumni's Reflection on The Link Between Innovative Pedagogy and Broader Humanistic Projects}

One interviewee spoke about her artists' residency project being at the cross-section between the pedagogical and broader humanistic implementations of art. While promoting the resident artists through publications, mentorship and other venues, the project requires the artists to be beneficial to the local community, especially the underprivileged part of it.

"Along with my ten-year-old studio practice I also run an artists' residency in the foothills of the Himalayas in a British Raj town, Murree. As an artist-run initiative, it supports visual artists by providing time and space for their projects. Our budget is extremely lean to easily lure private and corporate donors. We promote the artists through publications, mentorship from established artists and artist talks in urban centers. The artists have to be beneficial for the local community of Murree in order to integrate and must have the spirit of giving back. They contribute to the hill by conducting drawing workshops for gypsy children and local Christian school boarders. Murree is a summer residence of the Gujjar gypsies, an indigenous, underprivileged tribe, who live in huts along a cliff. The children spend the day begging and collecting free food from a soup kitchen. The government has not provided them with basic utilities, health, education and jobs. My residency is the only structured spot in Murree where these children get a stimulating interaction, respect and a sense of security. The residency has a diverse staff, a transgender cook to prepare meals, and three Gujjar gypsies. This year a resident artist was from the Hazara community, from Quetta, a minority who is persecuted for being Shia Muslims, was selected. Because of their distinct facial features it is difficult for them to go undercover and end up fleeing to Europe for asylum. Two female resident artists from Karachi participated; their work is about the ongoing violence and ecological damage inflicted upon their city. We also had a South Korean female artist and a Japanese male artist. It is very difficult to get visas for foreigners due to strict restriction to counter terrorist influences from abroad. The foreign artists were most impressed by Pakistani hospitality and its unique culture. Both plan to revisit." (Saba Khan)

Reflecting on his post-Fulbright professional practice, another interviewee reported being more selective about his practices, especially when it comes to aligning his artistic aspirations with a (social) purpose:

"The biggest change that I have made in my practice since my experience in art school is that I have become more aware of and hence selective about what I want to spend my self-doing .... I know that everything is learning experience and hence prior to film school I would pounce on pretty much anything to be able to learn. Now I take that decision with more care. I know I will learn something from each experience but now I want what I am saying or making to also have a purpose that aligns with my intent as an artist." (Bilal Sami)

\section{CONCLUSION AND RECOMMENDATIONS}

All six interviewees held positive opinions about their Fulbright studies in the U.S.A. Moreover, when interacting with domestic students on their return to Pakistan, the Fulbright graduates were transferring the knowledge and experiences they received abroad, thus becoming informal ambassadors of new ideas and practices. As indicated in the interviews, the participants' stay in the U.S.A. in some cases had given a boost to the artists' own creative abilities. As these Pakistani international alumni are succeeding in their careers, they may acquire more influence in their academic setting and, possibly, in the broader political and cultural contexts of their county. In view of the recognized potential of international graduates to influence their countries' academic, economic, political and cultural development, it is crucial to establish closer contacts with Pakistani international alumni, as well as maintain these links for extended periods. Finding a way to keep such contacts alive may ultimately lead to successes in future developments of internationalization in higher education. 
Some practical steps to establish and maintain links with international alumni in Pakistan have already been taken. In 2008, the U.S. Embassy in Islamabad launched the Pakistan-U.S. Alumni Network (PUAN), an association of U.S. exchange alumni who are committed to making meaningful contributions to Pakistan through community service, conferences, mentoring future generations, and reaching out to inspire and recruit new exchange participants. As of 28 December 2016, the PUAN website provided articles on such themes as alumni success stories, women's empowerment, and exploring visual culture with handicapped students (Pakistan-U.S. Alumni Network, 2016). A systematic study of these and other materials archived on PUAN website, as well as extensive field working among Pakistani graduates of U.S. school of higher education, may become one of the steps in building a conceptual framework of research on international alumni.

\section{REFERENCE LIST}

Abbas, S. B. (2015). International educational exchange programs as a modality of public diplomacy: An indepth analysis of the Fulbright Pakistan program. ProQuest Dissertations Publishing.

Altbach, P. (2013). Brain Drain or Brain Exchange: Developing Country Implications. International Higher Education, 72.

Amazan, R.C. (2014). When the Diaspora Returns: Analysis of Ethiopian Returnees and the Need for Highly Skilled Labor in Ethiopia. Internationalization of Higher Education and the Global Mobility, ed. Bernhard Streitwiser. Oxford: Symposium Books.

Banks, M. \& Bhandari, R. (2012). Global Student Mobility. SAGE Handbook of International Higher Education, ed. Darla K. Deardorff, Hans de Wit and John D. Heyl. SAGE Publications. http://site.ebrary.com.proxy.bsu.edu/lib/bsu/reader.action?doclD=10773012\&ppg=16

Barth, S. (1998). Globetrotting for Gifts. Currents, 24 (4).

Basinger, J, (1999). More U.S. Colleges Court Their Foreign Alumni. Chronicle of Higher Education 45 (33). ERIC, EBSCOhost.

Biraimah, K. L., \& Jotia, L. The Longitudinal Effects of Study Abroad Programs on Teachers' Content Knowledge and Perspectives: Fulbright-Hays Group Projects Abroad in Botswana and the SouthEast Asia. Journal of Studies in International Education, 17 (4).

Clift, K. (2010). Long-Distance Connection. Currents, 36 (7).

Connor, C. M. Earning the Right to Ask. Currents, 25 (9).

Cuthbert, D., Smith, W., \& Boey, J. (2008). What Do We Really Know About the Outcomes of Australian International Education? A Critical Review and Prospectus for Future Research. Journal of Studies in International Education, 12 (3).

Demir, C. E., Aksu, M.. \& Paykoç, F. (2000). Does the Fulbright Make a Difference? The Turkish Perspective. Journal of Studies in International Education.

de Wit, H. \& Urias, D. (2012). An Overview and Analysis of International Education Research, Training, and Resources. SAGE Handbook of International Higher Education, ed. Darla K. Deardorff, Hans de Wit and John D. Heyl, SAGE Publications.

http://site.ebrary.com.proxy.bsu.edu/lib/bsu/reader.action?doclD=10773012\&ppg=16

Han, X., Stocking, G., Gebbie, M. A., Appelbaum, R.P. (2015). Will They Stay or Will They Go? International Graduate Students and Their Decisions to Stay or Leave the U.S. upon Graduation. PLoS One. 10 (3). http://www.ncbi.nlm.nih.gov/pmc/articles/PMC4356591/

Higson, H. S., \& Liu, K. (2013). Business Lessons Without Business. Can Arts-Based Training Enhance Cultural Competence? Cross-Cultural Teaching and Learning for Home and International Students, ed. Janette Ryan. Routledge.

Hudzik, J.K. (2015). Comprehensive Internationalization. London, New York: Routledge. 
IJAEDU- International E-Journal of Advances in Education, Vol. III, Issue 9, December 2017

Hudzik, J. K., \& Stoh, M. Comprehensive and Strategic Internationalization of U.S. Higher Education. SAGE Handbook of International Higher Education, ed. Darla K. Deardorff, Hans de Wit and John D. Heyl,. SAGE Publications. http://site.ebrary.com.proxy.bsu.edu/lib/bsu/reader.action?doclD=10773012\&ppg=16

IIE - IFP Alumni Tracking Study (2017). https://www.iie.org/en/Research-and-Insights/IFP-Alumni-TrackingStudy

IIE Releases Open Doors 2016 Data. Press Release. Institute of International Education. https://www.iie.org/Why-IIE/Announcements/2016-11-14-Open-Doors-Data

Internationalizing Higher Education Worldwide. (2015). National Policies and Programs. American Council of Education. https://www.acenet.edu/news-room/Documents/National-Policies-and-Programs-Part-1Global.pdf

Mellors-Bourne, R., Humfrey, C., Kemp, N., \& Woodfield, S. (2013). Wider Benefits of International Higher Education in the UK. BIS Research Paper, 128.

https://www.gov.uk/government/uploads/system/uploads/attachment_data/file/240407/bis-13-1172the-wider-benefits-of-international-higher-education-in-the-uk.pdf

Pakistan-U.S. Alumni Network. (2016). Strengthening People-to-People Ties between U.S. and Pakistan. http://www.pakusalumninetwork.com/

Pulley, J, (2009). Continental Drift: International Students Become International Alumni and Create International Institutions. Currents, 35 (9).

Read, L. S. (2009). Challenges of Creating and Maintaining International Alumni Relations Programs. M.S. thesis, Oregon State University.

Rumbley, L. E., Altbach, P. A., \& Reisberg, L. (2012). Internationalization Within the Higher Education Context. SAGE Handbook of International Higher Education, ed. Darla K. Deardorff, Hans de Wit and John D. Heyl. SAGE Publications. http://site.ebrary.com.proxy.bsu.edu/lib/bsu/reader.action?doclD=10773012\&ppg=16

Saxenian, A. (2005). From Brain Drain to Brain Circulation: Transnational Communities and Regional Upgrading in India and China. University of California, Berkeley School of Information. http://people.ischool.berkeley.edu/ anno/Papers/scid-2005.pdf

Sporn, B. (2007). Governance and Administration: Organizational and Structural Trends. International Handbook of Higher Education, ed. James G.F. Forest and Philip G. Altback. London, New York: Springer.

Teferra, D. (2005). Brain Circulation: Unparalleled Opportunities, Underlying Challenges, and Outmoded Presumption. Journal of Studies in International Education, 9 (3).

Tubin, D,, \& Lapidot, O. (2008). Construction of "Glocal" (Global-Local) Identity among Israeli Graduate Students in the USA. Higher Education: The International Journal of Higher Education and Educational Planning 55 (2). ERIC, EBSCOhost

Wadhwa, V. (2009). Tapping Talent in a Global Economy: A Reverse Brain Drain. Issues in Science and Technology, XXV (3). http://issues.org/25-3/wadhwa-2/

Walker, N. (2011). Tending the Flock. Currents, 37 (3).

Wilhelm, I. (2013). Fulbright Starts Efforts to Help Alumni Keen Global Ties. Chronicle of Higher Education, 60 (9).

http://chronicle.com/article/Fulbright-Program Introduces/142643/?key=QTh7Ilg+YXFBYCpgNGtBbDZRPXFpZk8uNXVMbHwhblpcEQ 